\title{
USDA Forest Service Roadless Areas: Potential Biodiversity Conservation Reserves
}

\author{
$\underline{\text { Colby Loucks }}^{1}, \underline{\text { Nicholas Brown }}^{2}, \underline{\text { Andrea Loucks }}^{3}$, and $\underline{\text { Kerry Cesareo }}^{1}$
}

\begin{abstract}
In January 2001, approximately $23 \times 10^{6}$ ha of land in the U.S. National Forest System were slated to remain roadless and protected from timber extraction under the Final Roadless Conservation Rule. We examined the potential contributions of these areas to the conservation of biodiversity. Using GIS, we analyzed the concordance of inventoried roadless areas (IRAs) with ecoregion-scale biological importance and endangered and imperiled species distributions on a scale of 1:24,000. We found that more than $25 \%$ of IRAs are located in globally or regionally outstanding ecoregions and that $77 \%$ of inventoried roadless areas have the potential to conserve threatened, endangered, or imperiled species. IRAs would increase the conservation reserve network containing these species by $156 \%$. We further illustrate the conservation potential of IRAs by highlighting their contribution to the conservation of the grizzly bear (Ursos arctos), a wide-ranging carnivore. The area created by the addition of IRAs to the existing system of conservation reserves shows a strong concordance with grizzly bear recovery zones and habitat range. Based on these findings, we conclude that IRAs belonging to the U.S. Forest Service are one of the most important biotic areas in the nation, and that their status as roadless areas could have lasting and far-reaching effects for biodiversity conservation.
\end{abstract}

\section{INTRODUCTION}

In January 2001, the Clinton administration promulgated its Roadless Area Conservation Rule, which states that $237,000 \mathrm{~km}^{2}$ of inventoried roadless areas (IRAs) within the U.S. National Forest System will remain roadless and protected from timber extraction (USDA Forest Service 2000). These lands represent $31 \%$ of the National Forest System or $2.5 \%$ of the total U.S. land base (DeVelice and Martin 2001). They would increase the amount of strictly protected land area in the United States in IUCN categories I-III from 4.8 to $8.5 \%$. Beyond these most basic statistics, few studies have analyzed the potential contribution of IRAs to biodiversity conservation (Martin et al. 2000, DeVelice and Martin 2001).

DeVelice and Martin (2001) assessed the extent to which IRAs could contribute to building a representative network of conservation reserves in the United States. Using ecoregions as their unit of analysis (Ricketts et al. 1999), they found that IRAs could potentially expand ecoregional representation, increase the area of reserves at lower elevations, and increase the size of conservation areas to provide refuge for wide-ranging species. However, in their assessment they did not evaluate the contribution of IRAs toward the conservation of biodiversity and populations of specifically threatened, endangered, or imperiled species.

The lands belonging to the USDA Forest Service contain more than $80 \%$ of mammal and reptile species and more than $90 \%$ of the bird, amphibian, and fish species in the United States, including many that have been extirpated from large portions of their presettlement ranges (USDA Forest Service 1997). According to the NatureServe database, more than 1400 of these species have been designated as threatened and endangered (TE) species under the Endangered Species Act (ESA). The Forest Service Roadless Area Final Environmental Impact Statement identified approximately $400 \mathrm{TE}$ or proposed species found on USDA Forest Service land and an estimated $220(55 \%)$ that are directly or indirectly associated with IRAs (USDA Forest Service 2000). IRAs provide or influence designated critical habitat for at least 30 of these species (USDA Forest Service 2000).

However, the ESA list is not a complete listing of imperiled species. There are numerous species that are globally rare or threatened with extinction but for 
various reasons do not appear on the ESA TE species list. Many of these species also occur on USDA Forest Service land. To fill this gap, we supplemented the TE species list with species categorized as critically imperiled or imperiled according to NatureServe's central database.

The objective of this paper is to assess three critical questions associated with IRAs:

Is there a high concordance between IRAs and ecoregions of particular biodiversity values?
Do IRAs overlap with threatened, endangered, or imperiled species?

Is there potential for IRAs to assist in the conservation of wide-ranging species, such as the threatened grizzly bear (Ursos arctos horribilis), in the conterminous United States?

\section{METHODS}

We obtained the spatial coverages of the inventoried road areas (IRAs) in vector format from the roadless area conservation Web site (Table 1).

Fig. 1. Overlap of USDA Forest Service inventoried roadless areas (IRAs) with ecoregions that contain USDA Forest Service lands. The bold line indicates the separation of IRAs into three geographic regions: east, west, and Alaska.

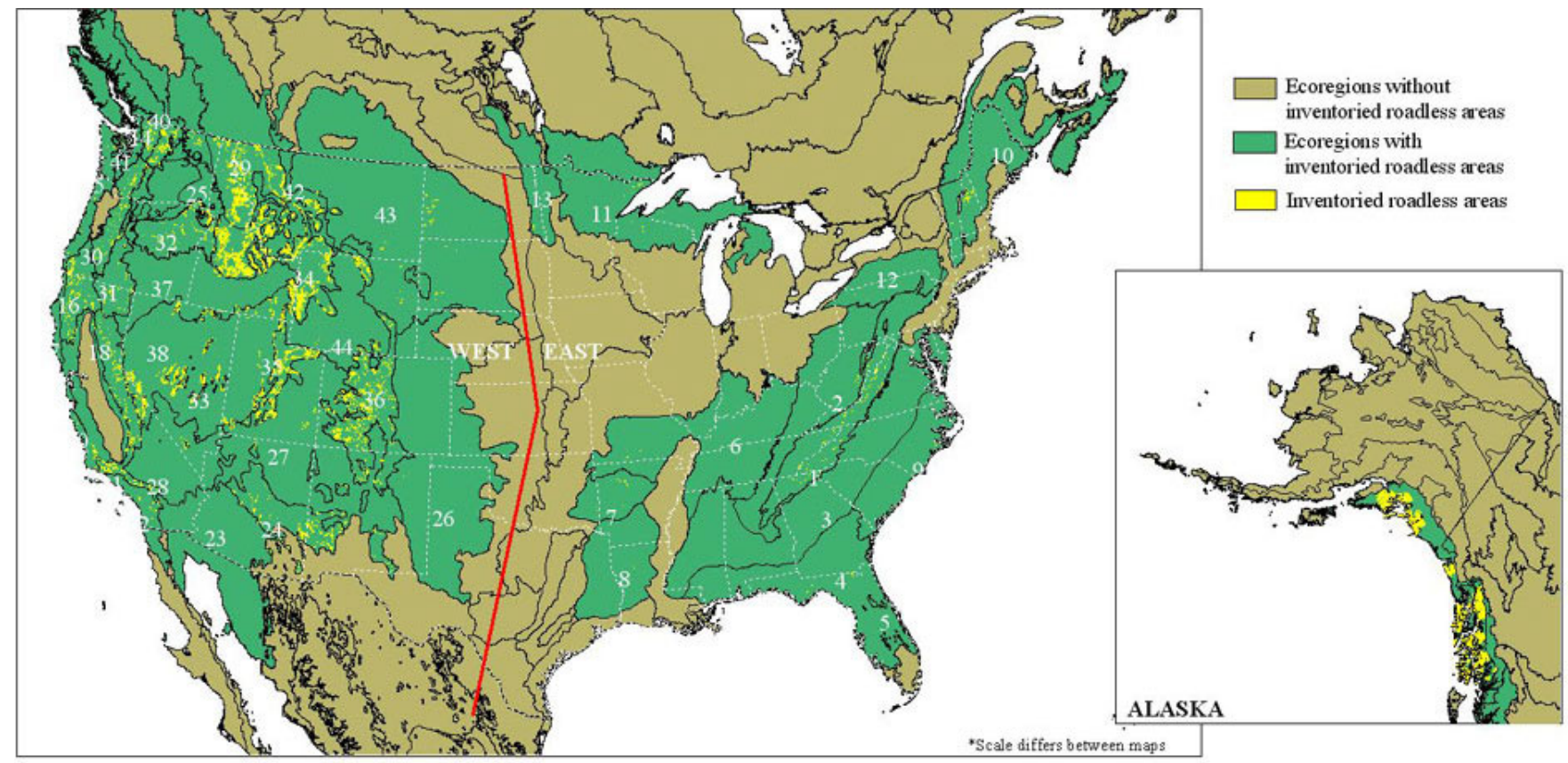

1. Appalachian-Blue Ridge Forests

2. Appalachian Mixed Mesophytic Forests

3. Southeastem Mixed Forests

4. Southeastem Conifer Forests

5. Florida Sand Pine Scrub

6. Central US Hardwood Forests

7. Ozark Mountain Forests

8. Piney Woods Forests

9. Middle Atlantic Coastal Forests

10. New England-A cadian Forests

11. Westem Great Lakes Forests

12. Allegheny Highlands Forests

13. Northern Tall Grasslands

14. British Columbia Mainland Coastal Forests

15. Central Pacific Coastal Forests

16. Klamath-Siskiyou Forests
17. Northern Califomia Coastal Forests 18. Sierra Nevada Forests

19. Madrean Sky Islands Montane Forests

20. California Interior Chaparral \& Woodlands

21. California Montane Chaparral \& Woodlands

22. California Coastal Sage \& Chaparral

23. Sonoran Desert

24. Arizona Mountains Forests

25. Palouse Grasslands

26. Western Short Grasslands

27. Colorado Plateau Shrublands

28. Mojave Desert

29. North Central Rockies Forests

30. Central and Southern Cascades Forests

31. Eastern Cascades Forests

32. Blue Mountains Forests
33. Great Basin Montane Forests

34. South Central Rockies Forest

35. Wasatch and Uinta Montane Forests

36. Colorado Rockies Forests

37. Snake-Columbia Shrub Steppe

38. Great Basin Shrub Steppe

39. Okanogan Forests

40. Cascade Mountains Leeward Forests

41. Puget Lowland Forests

42. Montana Valley and Foothill Grasslands

43. Northwestern Mixed Grasslands

44. Wyoming Basin Shrub Steppe

45. Northem Pacific Coastal Forest

46. Pacific Coastal Mountain Tundra \& Ice Fields 
Table 1. Data sources. All data web data sources were accessed in February 2001.

\begin{tabular}{ll}
\hline Database name & Source \\
\hline USDA Forest Service roadless area database & $\frac{\text { http://roadless.fs.fed.us/documents/feis/data/gis/coverag }}{\text { es/index.shtml }}$ \\
World Wildlife Fund ecoregions database & Ricketts et al. 1999 \\
NatureServe central databases & NatureServe \\
Protected areas database & Conservation Biology Institute and World Wildlife Fund \\
Grizzly bear recovery area boundaries & $\begin{array}{l}\text { U.S. Fish and Wildlife Service and University of } \\
\text { Montana }\end{array}$ \\
\hline
\end{tabular}

\section{Ecoregions}

As seen in Fig. 1 and Table 1, we evaluated the potential benefit of IRAs for biodiversity conservation using the ecoregions and biological importance rankings provided in Ricketts et al. (1999). Using ArcView 3.2, we combined the IRAs and ecoregion coverages, both in vector format. To facilitate interpretation, we separated our analysis into three geographic regions, i.e., the eastern United States, the western United States, and Alaska, following the methodology used by DeVelice and Martin (2001).

Ricketts et al. (1999:7) defined an ecoregion as " ... a relatively large area of land or water that contains a geographically distinct assemblage of natural communities." Ecoregions were selected as the units of analysis because they integrate ecological, biological, and geographic considerations into land-use decision making and are being used to establish priorities for large-scale conservation efforts (Omernik 1995a,b, Ricketts et al. 1999, Groves et al. 2002). Where ecoregions extend into either Canada or Mexico, we included only those portions within U.S. boundaries for all analyses. Although we would have preferred to maintain ecoregional contiguity, the spatial nature of USDA Forest Service lands and the applicability of the Endangered Species Act required strict adherence to political boundaries.
Ricketts et al. (1999) classified the biological importance of each ecoregion based on species distribution, i.e., richness and endemism, rare ecological or evolutionary phenomena such as largescale migrations or extraordinary adaptive radiations, and global rarity of habitat type, e.g., Mediterraneanclimate scrub habitats. They used species distribution data for seven taxonomic groups: birds, mammals, butterflies, amphibians, reptiles, land snails, and vascular plants (Ricketts et al. 1999). Each category was divided into four rankings: globally outstanding, high, medium, and low. The rankings for each of the four categories were combined to assign an overall biological ranking to each ecoregion. Ecoregions whose biodiversity features were equaled or surpassed in only a few areas around the world were termed "globally outstanding." To earn this ranking, an ecoregion had to be designated "globally outstanding" for at least one category. The second-highest category, or continentally important ecoregions, were termed "regionally outstanding," followed by "bioregionally outstanding" and "nationally important" (Ricketts et al. 1999). Although our analyses focused on those ecoregions characterized as globally and regionally outstanding, even the lowest category, nationally important, contains important biodiversity in a local context.

\section{Threatened, endangered, and imperiled species}

Currently, public land managers are required to 
monitor populations of threatened and endangered (TE) species and, where appropriate, develop management plans to conserve these populations and their habitat requirements (U.S. Fish and Wildlife Service 1973). Previous studies have analyzed the distribution of TE species based on counties, or boroughs in Alaska, and identified high-concentration areas of TE species and associated habitats (Dobson et al. 1997, Flather et al. 1998, Stein et al. 2000). Despite their valuable findings, these previous studies were limited by the coarse level of spatial resolution and the use of political units of disparate sizes. To avoid similar limitations with our analysis, we use data of a finer resolution to identify levels of concordance between the locations of IRAs and TE species.

The NatureServe central database (Table 1) provided the finer-resolution data for the identification of the locations of TE species. Data for this database are developed by state natural heritage programs and managed by NatureServe. Natural heritage programs have documented and tracked the occurrence of threatened, endangered, and imperiled species for nearly $30 \mathrm{yr}$ (Jenkins 1985, 1988, 1996). The system assigns global conservation status ranks known as "element global ranks" or "G-RANKS" to species and communities that are intended to estimate the extent of their imperilment or vulnerability. Conservation status ranks are assigned based on an assessment of rarity, the extent of recent decline of populations, threats, biological fragility, and other factors (Stein et al 2000). The most imperiled species and communities are ranked G1, and the most stable ones are ranked G5.

The NatureServe central database includes fields for federal ESA listing status and for global conservation status. We selected records of species that are federally listed as threatened or endangered (TE) according to the U.S. Fish and Wildlife Service or the National Marine and Fisheries Service and those that are ranked by NatureServe as critically imperiled (G1) or imperiled (G2). The output file was a vector file of 109,125 occurrences of species with G1 or G2 rankings or federal ESA listings. These occurrences were collated into 7.5-min quadrangles from the U.S. Geological Survey. The largest quadrangles, in the southern part of the United States, are $179 \mathrm{~km}^{2}$. We used two data products for our analyses. The first contains only TE species (Fig. 2), and the second contains TE, G1, and G2 species (Fig. 3). The spatial resolution of the locational data varied according to the equipment and methodologies that natural heritage programs used in collecting the data. However, the maximum uncertainty for the data set was less than the area of a quadrangle grid cell.

Fig. 2. Threatened and endangered (TE) species distributions by the 7.5-min quadrangles of the U.S. Geological Survey.

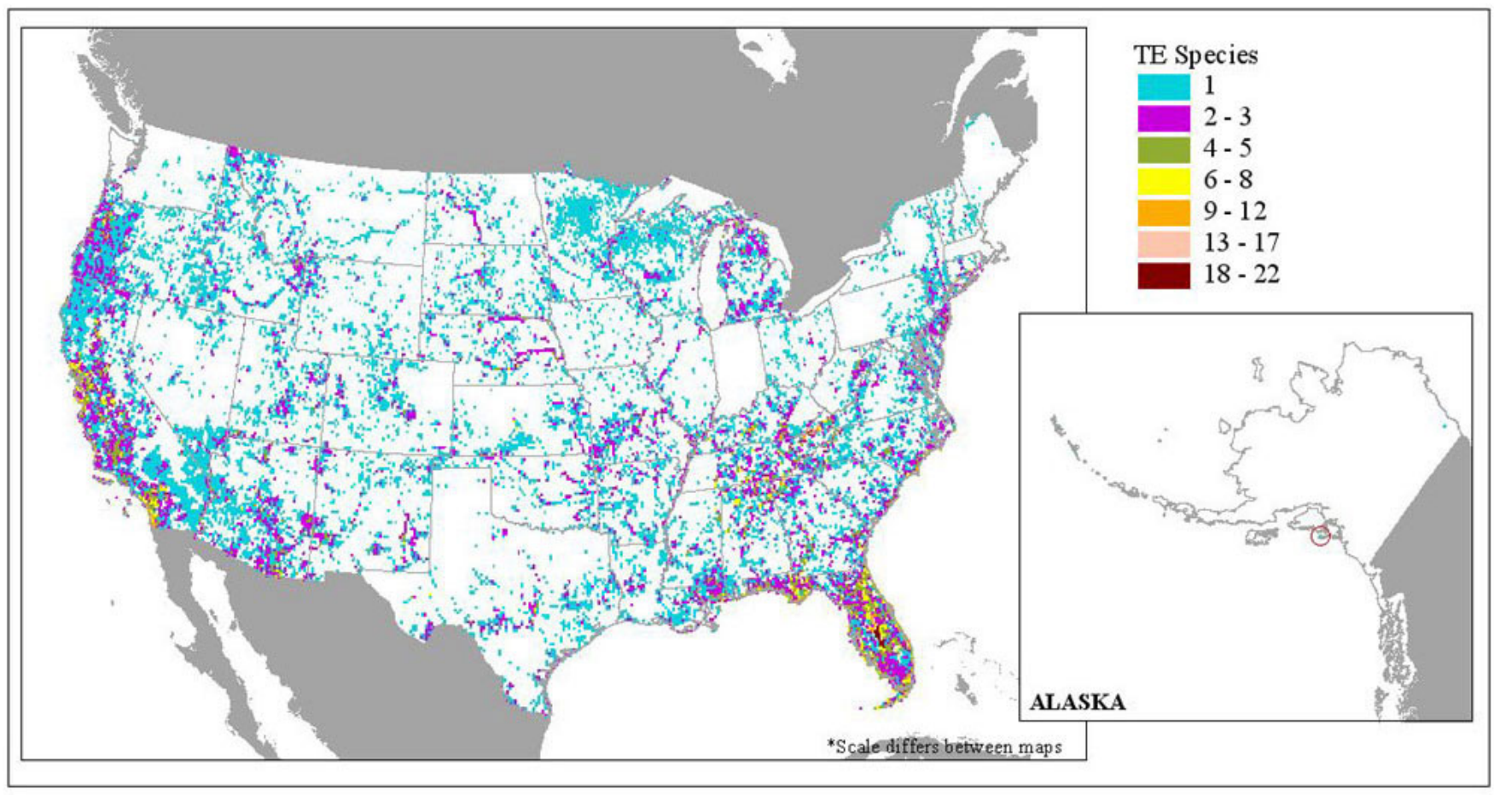


Fig. 3. Threatened and endangered (TE) species and critically imperiled (G1) and imperiled (G2) species distributions by the 7.5-min quadrangles of the U.S. Geological Survey.

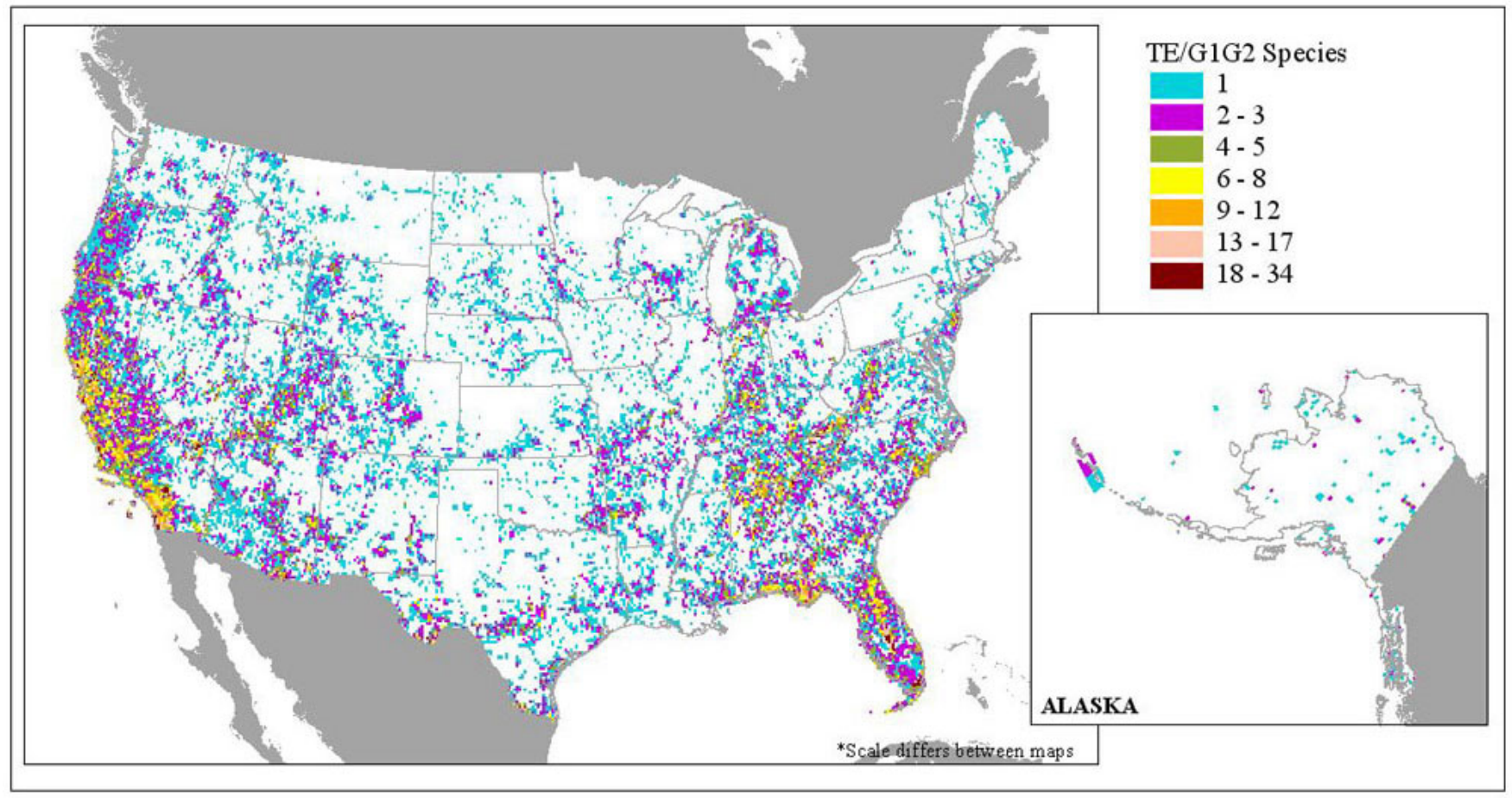

The TE, G1, and G2 data sets demonstrate only a moderate degree of overlap. These discrepancies occur partly because the NatureServe system evaluates only biological factors, whereas species are assigned to federal listings for both scientific and political reasons. There are 75,000 occurrences of TE species, but only 27,000 are ranked G1 or G2 by the NatureServe system. Of the 1409 ESA-listed TE species in the NatureServe database, 1109 are ranked G1 or G2. Conversely, there are 5997 species ranked G1 or G2 that are not classified as TE species. Of the 61,000 occurrences of G1 and G2 species recorded in the NatureServe database, more than 33,000 occurrences lack a TE species designation. One of the reasons for the disparity between the high concordance of species but the low concordance of occurrences is the fact that certain species are wide-ranging. For example, the grizzly bear, which is a threatened species but not a G1 or G2 species, is recorded often across its wide range, so that it accounts for far more records than a narrow endemic species that is both TE and listed as G1 or G2.

The NatureServe database contains information gaps (Table 2). However, although the missing data for Idaho, Montana, and Washington are critical for the conservation of individual species, the lack of them served only to make our analysis a more conservative estimate of the potential contributions of IRAs to species conservation. There are no IRAs in Massachusetts and only one in Maine, with a total area of $24 \mathrm{~km}^{2}$.

We overlaid both the TE species and TE/G1-G2 species databases with the uniquely named IRAs to identify the percentage of IRAs that contain known occurrences of TE or G1-G2 populations. In instances where multiple quadrangles containing species occurred within a single IRA unit, we erred on the conservative side and used only the quadrangle that contained the most species, i.e., we assumed that multiple quadrangles would contain the same species.

We also analyzed the relative increase in conservation reserves that IRAs would confer to TE and TE/G1-G2 species. We overlaid the TE and TE/G1-G2 databases with a conservation area database compiled by the Conservation Biology Institute and World Wildlife Fund (Table 1). This database includes all federal, state, county, and municipal public lands and some private lands. The private lands have not been systematically surveyed and do not include 
conservation easements. We used only lands that are classified for strict biodiversity conservation, which we define as those designated as categories I-III by the IUCN. Category I is for Strict Nature Reserves/Wilderness Areas, category II covers National Parks, and category III includes National Monuments (The World Conservation Union 1978, The World Conservation Union 1994). Hereafter we refer to the areas that meet these criteria as "conservation reserves." We did not include protected- area categories IV-VI, which allow road building, timber harvesting, and other extractive activities in our analysis. Of $78 \times 10^{6}$ ha of National Forest land, $14 \times$ $10^{6}$ ha are designated as National Wilderness Areas, and an additional $2.5 \times 10^{6}$ ha are classified as Special Designated Areas that are IUCN category I reserves. The remaining $61.5 \times 10^{6}$ ha of National Forest land, which are not classified as conservation reserves, are governed by periodic management plans that may allow or restrict resource uses and extraction.

Table 2. Gaps in data available for this study.

\begin{tabular}{ll}
\hline State & Missing data \\
\hline Idaho & Fish data \\
Maine & Animal data \\
Massachusetts & All data \\
Montana & Canada lynx, bull trout, gray wolf data \\
Washington & Most animal data \\
\hline
\end{tabular}

\section{Grizzly bear case study}

Finally, because national analyses can obscure important details of individual species, we also analyzed the potential contribution of IRAs to grizzly bears (Ursos arctos horribilis), specifically in relation to the regions designated as grizzly bear recovery areas by the U.S. Fish and Wildlife Service (Table 1). We overlaid these grizzly bear recovery zones with the IRAs to assess the concordance of these areas. We chose grizzly bears because they are a federally listed threatened species in the conterminous United States and require large and contiguous habitat areas to survive.

All spatial databases were in vector format and put into a common projection prior to the overlap analysis. All spatial estimates derived from our analyses were obtained by summarizing the area of overlap of the respective GIS databases. One caveat of our methodology is that the combination of multiple GIS layers may lead to the propagation of spatial errors and increased uncertainty (Flather et al. 1998, Heuvelink 1998). This concern is a generalized methodological one. Our errors are no greater or smaller than those of any similar analysis that uses multiple spatial data from multiple sources. The TE species databases, protected areas database, and IRA coverages represent a vast collection of data from many sources. It is likely that errors are associated with each of these layers. However, most of our analyses were conducted at a sufficiently broad scale that we believe the error rate is not large enough to affect our ultimate conclusions.

\section{RESULTS}

\section{Ecoregions}

Across the United States, we found that more than $20 \%$ of inventoried roadless areas (IRAs) were located within ecoregions that have been classified as globally outstanding (Table 3, Fig. 4). In the eastern region, approximately $70 \%$ of the IRAs are found in globally or regionally outstanding ecoregions (Table 3, Fig. 4). More than $50 \%$ of these forests occur in two Appalachian ecoregions, the Appalachian-Blue Ridge forests and the Appalachian mixed mesophytic forests. Both are considered globally outstanding for their diverse endemic species, which range across many 
taxa (Stephenson et al. 1993, Ricketts et al. 1999). The vast majority of the IRAs in eastern forests are less than $10.1 \mathrm{~km}^{2}$ in size, and few are adjacent to existing wilderness areas (DeVelice and Martin 2001).

Table 3. Distribution of inventoried roadless areas (IRAs) by category of ecoregion biodiversity as per Ricketts et al. (1999). The percentage is the percentage of IRAs that fall into that particular category.

\begin{tabular}{lcc}
\hline Biodiversity category & $\mathrm{km}^{2}$ & Percentage \\
\hline Globally outstanding & 50,221 & 21.2 \\
Regionally outstanding & 12,648 & 5.4 \\
Bioregionally outstanding & 164,600 & 69.5 \\
Nationally important & 9268 & 3.9 \\
\hline
\end{tabular}

Fig. 4. Overlap of USDA Forest Service inventoried roadless areas and ecoregions classified by biological importance (see Ricketts et al. 1999).

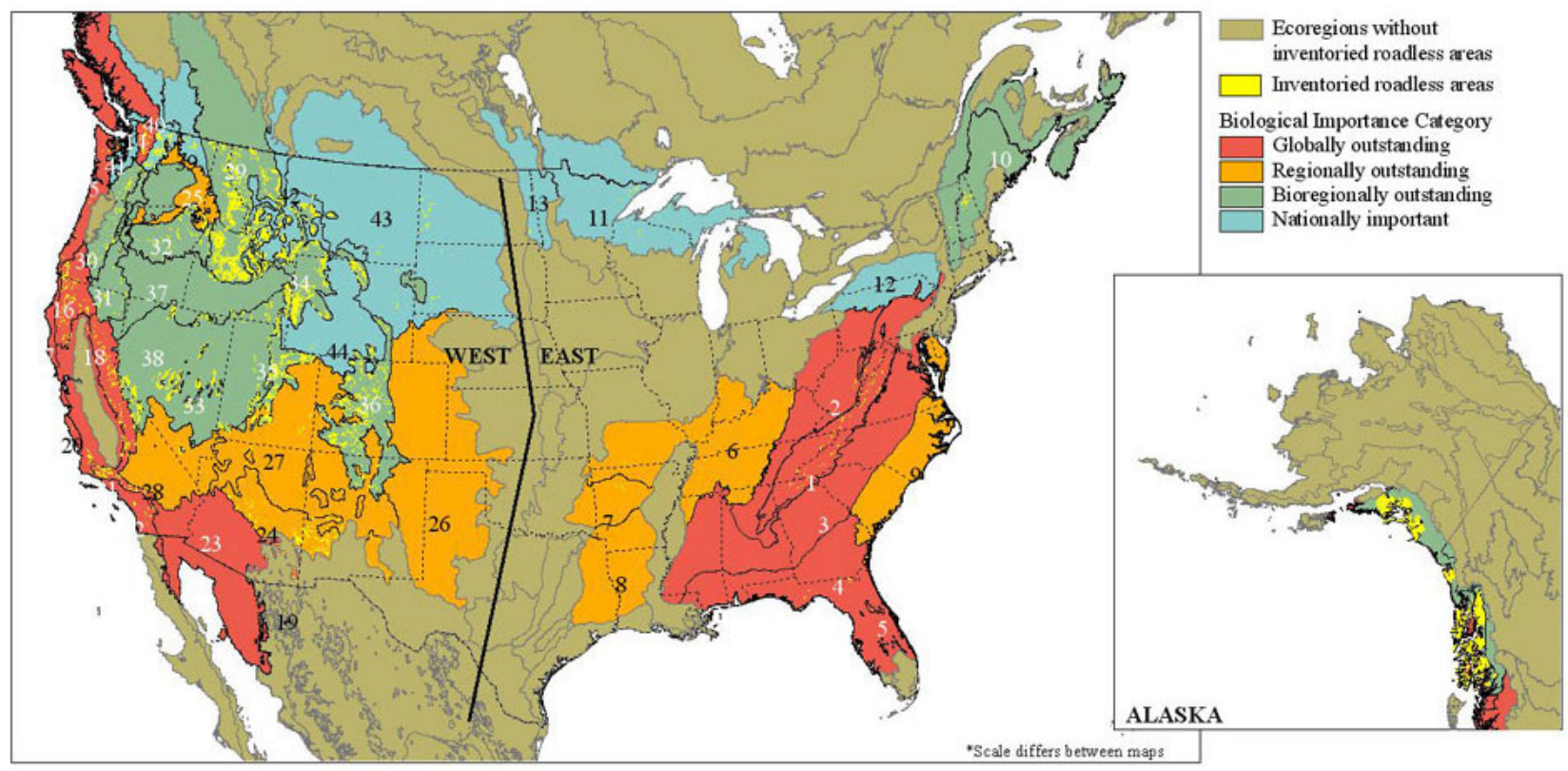

1. Appalachian-Blue Ridge Forests

2. Appalachian Mixed Mesophytic Forests

3. Southeastem Mixed Forests

4. Southeastern Conifer Forests

5. Florida Sand Pine Scrub

6. Central US Hardwood Forests

7. Ozark Mountain Forests

8. Piney Woods Forests

9. Middle Atlantic Coastal Forests

10. New England-A cadian Forests

11. Westem Great Lakes Forests

12. Allegheny Highlands Forests

13. Northern Tall Grasslands

14. British Columbia Mainland Coastal Forests

15. Central Pacific Coastal Forest

16. Klamath-Siskiyou Forests
17. Northern Califomia Coastal Forests 18. Sierra Nevada Forests

19. Madrean Sky Islands Montane Forests

20. California Interior Chaparral \& Woodlands

21. California Montane Chaparral \& Woodlands

22. California Coastal Sage \& Chaparral

23. Sonoran Desert

24. Arizona Mountains Forests

25. Palouse Grasslands

26. Western Short Grasslands

27. Colorado Plateau Shrublands

28. Mojave Desert

29. North Central Rockies Forests

30. Central and Southern Cascades Forests

31. Eastem Cascades Forests

32. Blue Mountains Forests
33. Great Basin Montane Forests

34. South Central Rockies Forests

35. Wasatch and Uinta Montane Forests

36. Colorado Rockies Forests

37. Snake-Columbia Shrub Steppe

38. Great Basin Shrub Steppe

39. Okanogan Forests

40. Cascade Mountains Leeward Forests

41. Puget Lowland Forests

42. Montana Valley and Foothill Grasslands

43. Northwestem Mixed Grasslands

44. Wyoming Basin Shrub Steppe

45. Northem Pacific Coastal Forests

46. Pacific Coastal Mountain Tundra \& Ice Fields 
In the western region, IRAs are found predominantly in bioregionally outstanding ecoregions, with only $18 \%$ in globally or regionally outstanding ecoregions (Table 3, Fig. 4). Although globally and regionally outstanding IRAs are found mainly in the states of California, Oregon, Washington, and Arizona, the intermountain west contains most of the nation's bioregionally and nationally important IRAs. Western IRAs are on average larger than eastern IRAs, and the vast majority are adjacent to existing wilderness areas. If the IRAs were combined with the wilderness areas, the western forests would contain 34 of the 45 largest contiguous areas of strictly protected forests in the United States (DeVelice and Martin 2001).

Table 4. Comparison of the degree of overlap between inventoried roadless areas (IRAs) and quadranges containing threatened or endangered (TE) species or quadranges containing TE species that are also ranked as highly imperiled (G1-G2) by the IUCN. The mean number of TE or TE/G1-G2 species present in each IRA is given.

\begin{tabular}{lccccc}
\hline Region & $\begin{array}{l}\text { Total no. of IRA } \\
\text { units } \dagger\end{array}$ & $\begin{array}{l}\text { No. of IRA units with TE } \\
\text { species quadrangles (\% of } \\
\text { total) }\end{array}$ & $\begin{array}{l}\text { Mean } \\
\text { no. of } \\
\text { species } \neq\end{array}$ & $\begin{array}{l}\text { No. of IRA units with } \\
\text { TE/G1-G2 species } \\
\text { quadrangles (\% of total) }\end{array}$ & $\begin{array}{l}\text { Mean } \\
\text { no. of } \\
\text { species } \ddagger\end{array}$ \\
\hline $\begin{array}{l}\text { Eastern United } \\
\text { States }\end{array}$ & 286 & $201(70.3)$ & 2.1 & $228(79.7)$ & 4 \\
$\begin{array}{l}\text { Western United } \\
\text { States }\end{array}$ & 2159 & $1317(61.0)$ & 1.6 & $1692(78.3)$ & 2.9 \\
Alaska & 150 & $2(1.3)$ & 1 & $88(58.6)$ & 1.3 \\
\hline
\end{tabular}

$\dagger$ Units are defined by each named inventoried roadless area.

\$Where multiple quadrangles occurred in a single IRA unit, we used only the quadrangle with the greatest number of species.

\section{Threatened, endangered, and imperiled species}

Of the 2595 IRA units, approximately $58 \%$ of them overlap with TE species quadrangles (Table 4). When separated into geographic regions, the IRAs in the eastern and western United States demonstrate overlaps of 70.3 and $61.0 \%$, respectively. Of the IRAs that contain TE species, the mean number of TE species found in IRAs is highest in the east (2.1 species) and lowest in Alaska (1.0 species).

When G1-G2 species are included in the analysis, both the number of IRAs that contain TE/G1-G2 species and the mean number of species of concern found in each IRA increase (Table 4). In sum, approximately $77 \%$ of the IRAs overlap with quadrangles that contain species at risk. The Alaska region contains the largest increase in IRAs when G1G2 species are included, increasing to 58.6 from $1.3 \%$. The west increases to $78.3 \%$, and the east increases to
$79.7 \%$. However, the east shows the largest increase in mean number of TE/G1-G2 species found in IRAs, increasing from 2.1 to 4.0 species (Table 4 ).

The IRAs could also contribute a significant amount of land area to existing conservation reserves for both TE and TE/G1-G2 species in all geographic regions (Table 5). The largest increase in area and the greatest percent increase in conservation reserves are found in the western United States, with the exception of the $100 \%$ increase from the single quadrangle in Alaska. IRAs would contribute to a $96 \%$ increase in available habitat in conservation reserves for TE species, whereas the inclusion of G1-G2 species expands that increase to $210 \%$. Although the eastern region would see similar but more modest gains, habitat in conservation reserves in the Alaska region would increase $113 \%$ for TE/G1-G2 species (Table 5). Overall, IRAs would increase the conservation reserve network containing TE, G1, or G2 species by $156 \%$. 
Table 5. The concordance of occurrences of threatened or endangered (TE) species or of TE species that are also classified as highly imperiled (G1-G2) by the IUCN with the existing conservation reserve network (IUCN I-III) and inventoried roadless areas (IRAs).

\begin{tabular}{lclclcl}
\hline \hline & $\begin{array}{l}\text { No. of TE species } \\
\text { quadrangles in IUCN } \\
\text { I-III conservation } \\
\text { reserves }\end{array}$ & $\begin{array}{l}\text { No. of TE } \\
\text { species } \\
\text { quadrangles in } \\
\text { IRAs }\end{array}$ & $\begin{array}{l}\text { Percent } \\
\text { increase }\end{array}$ & $\begin{array}{l}\text { No. of TE/G1- } \\
\text { G2 species } \\
\text { quadrangles in } \\
\text { IRAs }\end{array}$ & $\begin{array}{l}\text { No. of TE/G1-G2 } \\
\text { species quadrangles in } \\
\text { IUCN I-III } \\
\text { conservation reserves }\end{array}$ & $\begin{array}{l}\text { Percent } \\
\text { increase }\end{array}$ \\
\hline $\begin{array}{l}\text { Eastern United } \\
\text { States }\end{array}$ & 995 & 217 & 22 & 1027 & 431 & 42 \\
$\begin{array}{l}\text { Western United } \\
\text { States }\end{array}$ & 1752 & 1679 & 96 & 2200 & 4627 & 210 \\
Alaska & 0 & 1 & 100 & 38 & 43 & 113 \\
\hline
\end{tabular}

\section{Grizzly bear case study}

As seen in Fig. 5, the inclusion of IRAs in the existing system of conservation reserves in Washington, Idaho, Montana, and Wyoming shows a strong concordance with the grizzly bear recovery zones of the U.S. Fish and Wildlife Service, as well as bear habitat range (Martin et al. 2000, USDA Forest Service 2000). In total, the six grizzly bear recovery zones include approximately $15,300 \mathrm{~km}^{2}$ of IRAs. Approximately $24,750 \mathrm{~km}^{2}$ of almost contiguous IRAs surround the Salmon-Selway (Bitterroot) Recovery Zone (SSRZ), which has already been designated a wilderness area and assigned to IUCN category I.

\section{DISCUSSION}

Our analyses found that one-quarter of the inventoried roadless ares (IRAs) are found in globally or regionally outstanding ecoregions, and that they have the potential to provide important habitat for numerous species, including threatened, endangered, and imperiled species. This conclusion is further illustrated by an investigation of the potential benefit of IRAs to grizzly bear conservation.

Based on these findings, the assignment of IRAs to IUCN category III or higher could increase the area of conservation reserves in the United States from 4.8 to $8.5 \%$. This broad national conclusion has different implications depending on geographic region. For example, whereas fewer than $3 \%$ of the IRAs are found in the eastern United States, the vast majority of eastern IRAs are found in the ecoregions with the greatest amount of biodiversity and the least amount of existing protection. In addition, despite the fact that western forests currently have some of the highest existing protection levels in the United States, Scott et al. (2001) found that many existing reserves in the United States are concentrated in areas of high elevation and low soil productivity. Therefore, despite the current levels of perceived protection, the nation's biological diversity may be under-represented in the current system, particularly in the mountainous west (Scott et al. 2001). DeVelice and Martin (2001) have shown that approximately $40 \%$ (about $91,300 \mathrm{~km}^{2}$ ) of the IRAs are at an elevation below $1500 \mathrm{~m}$ and that $35 \%$ of the total IRAs are adjacent to designated wilderness areas. The combination of increased protection of forest habitat and the potential increase in size of conservation reserves would have a positive effect on the conservation of large mammals in the western United States.

The purpose of the Endangered Species Act is to " ... provide a means whereby the ecosystems upon which endangered and threatened species depend may be conserved ... " (U.S. Fish and Wildlife Service 1973). The act further directs that " ... all Federal departments shall seek to conserve endangered species and threatened species." In this regard, many IRAs function as biological refugia for terrestrial and aquatic species, including numerous threatened, endangered, and imperiled species. The maintenance of natural 
values in IRAs could contribute to their long-term viability (Brown and Archuleta 2000). IRAs contain more than $220 \mathrm{TE}$ species, i.e., approximately $25 \%$ of listed or proposed animal species and $13 \%$ of listed plant species (USDA Forest Service 2000).

Fig. 5. Overlap of USDA Forest Service inventoried roadless areas and grizzly bear recovery zones.

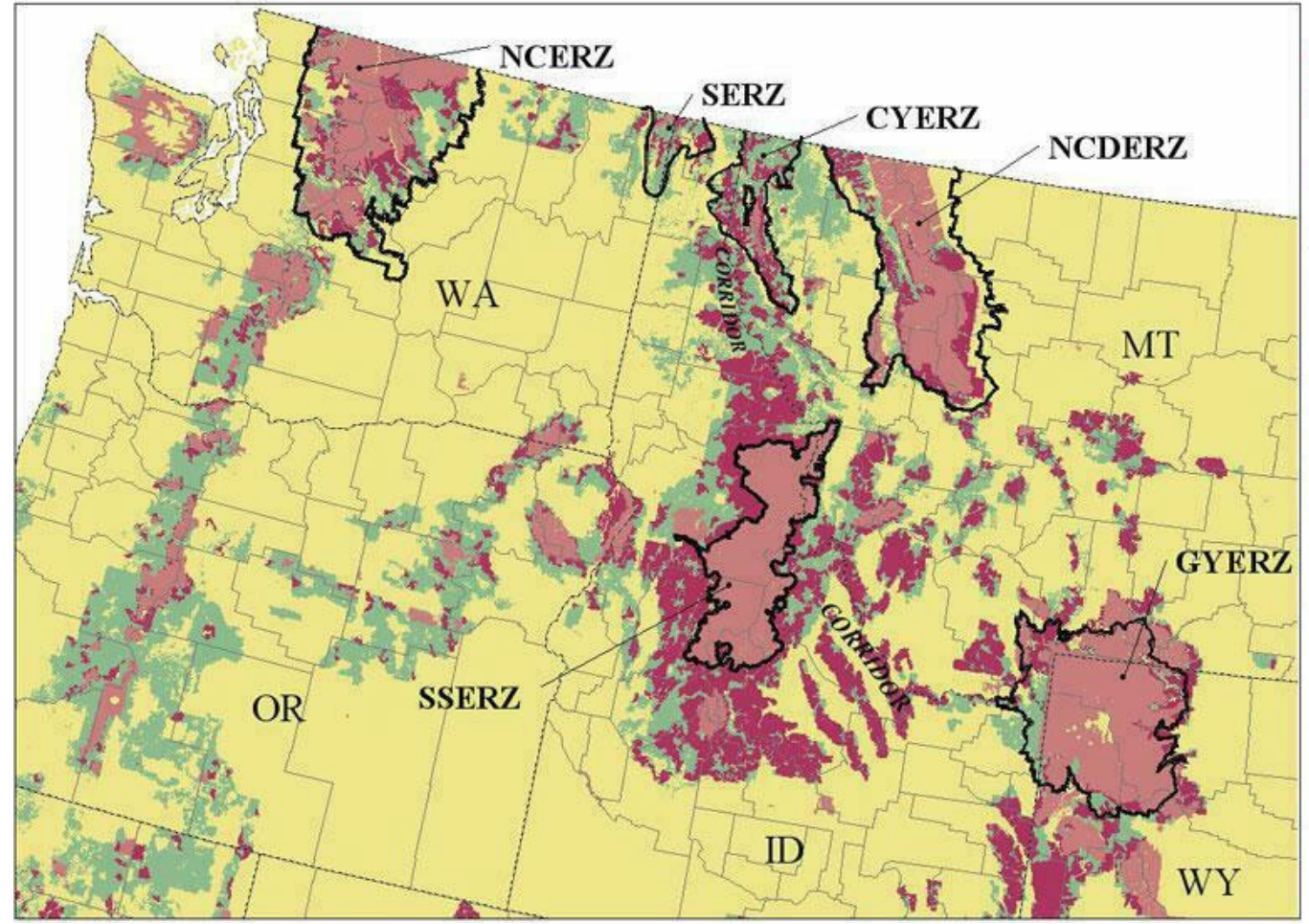

Inventoried roadless areas
IUCN II protected
areas
USDA Forest Service Land
Proposed grizzly
recovery zones

Among TE species, $88 \%$ are imperiled by habitat destruction and degradation (Wilcove et al. 1998). Dobson et al. (1997) found that, if the habitats of TE species were more extensively protected, a large number of them would be efficiently conserved. Our analysis showed that the vast majority of IRAs hosted TE or G1-G2 imperiled species and that, by adding the IRAs to the existing conservation reserve system, the conservation of species at risk and their habitat could be better realized. Although we recognize that not all threatened, endangered, or imperiled species require lands free of active land management to survive, limiting the human footprint by placing IRAs off limits to road construction and maintenance, resource extraction, and other development activities could provide a counterpoint to the multiple-use activities taking place elsewhere within the National Forest System.

Furthermore, although there may be duplicate species populations within IRAs or existing conservation reserves, the high level of endangerment of these species should predicate that we conserve as many populations as possible. Therefore, the potential issues of complementarity or duplication of species across IRAs should not diminish the contribution that IRAs could make to conserving species at risk. Our analyses have shown that, despite the small size and extent of IRAs in the eastern United States, they contain a greater number of endangered or imperiled species across more IRAs than do the west and Alaska. However, many of the western IRAs are missing data or have not been surveyed. This error of omission serves only to emphasize that our findings are a conservative estimate of potential species endangerment particularly in IRAs in Alaska and the western United States.

Top carnivore species, such as the grizzly bear, often have the largest species-level area requirements in an ecosystem and maintain ecological structures and resilience by top-down trophic interactions. They need 
large, contiguous habitat blocks to persist, and there must be landscape connectivity among core areas to ensure sufficient habitat for viable populations (Soulé and Noss 1998, Carroll et al. 2001). As a result of these requirements, large reserves are necessary to maintain populations of these wide-ranging species. Woodroffe and Ginsberg (1998) recently estimated that habitats of $20,000 \mathrm{~km}^{2}$ are needed to provide a $90 \%$ chance for the long-term survival of the grizzly bear in the wild. Indeed, only those wilderness areas that were $20,000 \mathrm{~km}^{2}$ or larger in 1920 still support grizzly bears today (Mattson and Merrill 2002). The $40,000 \mathrm{~km}^{2}$ of IRAs in and near designated grizzly recovery zones in the northern Rockies will help improve the long-term habitat viability for grizzly bears in the region (Martin et al. 2000, USDA Forest Service 2000).

Carroll et al. (2001) proposed the need for a comprehensive conservation strategy for carnivores in the Rocky Mountains that considers the requirements of several species, including grizzly bear, wolverine, fisher, and lynx. The regions where these four species overlap show a strong concordance with grizzly bear recovery zones. IRAs may benefit all of these species by providing expanded and buffered habitat and, in turn, secure the ecological integrity of those ecosystems (Terborgh and Soulé 1999, Conner et al. 2000, Martin et al. 2000). If grizzly bear populations remain limited by the size and configuration of current conservation reserves, their long-term survival in the conterminous United States cannot be assured (Mattson and Merrill 2002).

Bruner et al. (2001) found a clear relationship between the existence of a viable and well-connected system of conservation reserves and biodiversity conservation. Because of the stable long-term ownership tenure associated with USDA Forest Service lands, as opposed to privately held forests, many of these forested areas contain a wealth of biological diversity. Historically, land within the Forest Service has been managed under a multiple-use strategy, with timber extraction being a main component of many of these plans. However, multiple-use management may not ensure the protection of the full range of biodiversity, because anthropogenic habitat degradation and destruction are the primary causes of biodiversity loss (Ehrlich 1988, Myers 1988, Wilcove et al. 1996, Haila 1999, Wood 2000).

Setting aside IRAs for stricter protection from extractive or economically driven activities may indeed meet many biological objectives, e.g., integration of fish and wildlife values and watershed and forest health, consistent with the agency's multipurpose agenda. In addition, IRAs may also contribute invaluable benchmarks to gauge ecological changes on managed U.S. Forest Service lands. A representative system of natural habitats, set aside from active management, would allow natural ecological processes, including a full suite of existing native species, to survive free of human activities. Without strict conservation areas that represent all forest habitat types, it will be difficult to make objective assessments on the sustainability of forest management (Noss and Cooperrider 1994, Norton 1999, Noss et al. 1999). Based upon our analyses, we conclude that IRAs support many at-risk species and thereby greatly contribute to the conservation of biodiversity throughout the United States. For some species with only a few remaining populations, the strict and permanent protection of IRAs may represent the final, critical refuge.

Responses to this article can be read online at: http://www.consecol.org/vol7/iss2/art5/responses/index.html

\section{Acknowledgments:}

E. Dinerstein, N. Rana, T. Ricketts, R. Riordan, B. Stein, and three anonymous reviewers provided valuable comments on the development of this manuscript. NatureServe (www.natureserve.org) and its natural heritage member programs provided valuable locational data for TE and G1-G2 species. J. McNees of NatureServe provided valuable analyses of those data.

\section{LITERATURE CITED}

Brown, S., and R. Archuleta. 2000. Forest Service, roadless area conservation, final environmental impact statement: specialist report for terrestrial and aquatic habitats and species. USDA Forest Service, Washington, D.C., USA. Available online at http://216.239.37.104/search?q=cache:18IXbvJWIm4J:roadl ess.fs.fed.us/documents/feis/specrep/xbio_spec_rpt.pdf+bro $\underline{\mathrm{wn}+\% 22 \text { specialist+report+for+terrestrial } \% 22 \& \mathrm{hl}=\mathrm{en} \& \mathrm{ie}=\mathrm{U}}$ $\underline{\mathrm{TF}-8}$.

Bruner, A. G., R. E. Gullison, R. E. Rice, and G. A. B. da Fonseca. 2001. Effectivensss of parks in protecting tropical biodiversity. Science 291:125-128.

Carroll, C., R. F. Noss, and P. C. Paquet. 2001. Carnivores 
as focal species for conservation planning in the Rocky Mountain region. Ecological Applications 11:961-980.

DeVelice, R. L., and J. R. Martin. 2001. Assessing the extent to which roadless areas complement the conservation of biological diversity. Ecological Applications 11:10081018.

Dobson, A. P., J. P. Rodriguez, W. M. Roberts, and D. S. Wilcove. 1997. Geographic distribution of endangered species in the United States. Science 275:550-553.

Ehrlich, P. 1988. The loss of diversity: causes and consequences. Pages 21-27 in E. O. Wilson, editor. Biodiversity. National Academy Press, Washington, D.C., USA.

Flather, C. H., M. S. Knowles, and I. A. Kendall. 1998. Threatened and endangered species geography. Bioscience 48:365-376.

Groves, C. R., D. B. Jensen, L. L. Valutis, K. H. Redford, M. L. Shaffer, J. M. Scott, J. V. Baumgartner, J. V. Higgins, M. W. Beck, and M. G. Anderson. 2002. Planning for biodiversity conservation: putting conservation science into practice. BioScience 52:499-512.

Haila, Y. 1999. Islands and fragments. Pages 234-264 in M. L. Hunter Jr., editor. Maintaining biodiversity in forest ecosystems. Cambridge University Press, Cambridge, UK.

Heuvelink, G. B. M. 1998. Error propagation in environmental modeling with GIS. Taylor and Francis, London, UK.

Jenkins, R. E. 1985. Information methods: why the heritage programs work. Nature Conservancy News 35:21-23.

Jenkins, R. E. 1988. Information management for the conservancy of biodiversity. Pages 231-239 in E. O. Wilson, editor. Biodiversity. National Academy Press, Washington, D.C., USA.

Jenkins, R. E. 1996. Natural Heritage Data Center Network: managing information for biodiversity. Pages 176-192 in R. C. Szaro and D. W. Johnson, editors. Biodiversity in managed landscapes: theory and practice. Oxford University Press, New York, New York, USA.

Martin, J. R., R. L. DeVelice, and S. Brown. 2000. Forest Service, roadless area conservation, final environmental impact statement: landscape analysis and biodiversity specialist report. USDA Forest Service, Washington, D.C., USA. Available online at http://216.239.37.104/search?q=cache:3MEq9qtl6EwJ:roadl ess.fs.fed.us/documents/feis/specrep/xlandscape_spec_rpt.p $\mathrm{df}+$ martin+\%22landscape+analysis+and+biodiversity+speci alist+report\%22\&hl=en\&ie=UTF-8.

Mattson, D. J., and T. Merrill. 2002. Extirpations of grizzly bears in the contiguous United States, 1850-2000. Conservation Biology 16:1123-1136.
Myers, N. 1988. Tropical forests and their species: going, going ...? Pages 28-35 in E. O. Wilson, editor. Biodiversity. National Academy Press. Washington, D.C., USA.

Norton, D. 1999. Forest reserves. Pages 525-555 in M. L. Hunter, editor. Maintaining biodiversity in forest ecosystems. Cambridge University Press, Cambridge, UK.

Noss, R. F., and A. Y. Cooperrider. 1994. Saving nature's legacy. Island Press, Washington, D.C., USA.

Noss, R. F., E. Dinerstein, B. Gilbert, M. Gilpin, B. J. Miller, J. Terborgh, and S. Trombulak. 1999. Core areas: where nature reigns. Pages $99-128$ in M. E. Soulê and J. Terborgh, editors. Continental conservation: scientific foundations of regional reserve networks. Island Press. Washington, D.C., USA.

Omernik, J. M. 1995a. Ecoregions: a framework for managing ecosystems. George Wright Forum 12:35-51.

Omernik, J. M. 1995b. Level III ecoregions of the continent. U.S. Environmental Protection Agency, National Health and Environment Effects Research Laboratory, Washington, D.C., USA. Map at 1:7,500,000 scale.

Ricketts, T. H., E. Dinerstein, D. M. Olson, C. J. Loucks, W. Eichbaum, D. DellaSala, K. Kavanaugh, P. Hedao, P. T. Hurley, K. M. Carney, R. Abell, and S. Walters. 1999. Terrestrial ecoregions of North America: a conservation assessment. Island Press, Washington, D.C., USA.

Scott, J. M., F. W. Davis, R. G. McGhie, R. G. Wright, C. Groves, and J. Estes. 2001. Nature reserves: do they capture the full range of America's biological diversity? Ecological Applications 11:999-1007.

Soulé, M. E., and R. F. Noss. 1998. Rewilding and biodiversity: complementary goals for continental conservation. Wild Earth Fall:18-28.

Stein, B. A., L. S. Kutner and J. S. Adams, editors. 2000. Precious heritage: the status of biodiversity in the United States. Oxford University Press, Oxford, UK.

Stephenson, S. L., A. N. Ash, and D. F. Stauffer. 1993. Appalachian oak forests. Pages 255-304 in W. H. Martin, S. G. Boyce, and A. G. Echternacht, editors. Biodiversity of the southeastern United States: upland terrestrial communities. Wiley, New York, New York, USA.

Terborgh, J., and M. E. Soulé. 1999. Why we need megareserves: large-scale networks and how to design them. Wild Earth Spring:66-72.

USDA Forest Service. 1997. Report of the United States on the criteria and indicators for sustainable management of temperate and boreal forests. USDA Forest Service, Washington, D.C., USA.

USDA Forest Service. 2000. Forest Service, roadless area conservation, final environmental impact statement. USDA 
Forest Service, Washington, D.C., USA.

U.S. Fish and Wildlife Service. 1973. Endangered species act. Available online at http://endangered.fws.gov/esa.html.

Wilcove, D. S., M. J. Bean, R. Bonnie, and M. McMillan. 1996. Rebuilding the ark: toward a more effective Endangered Species Act for private land. Environmental Defense Fund, Washington, D.C., USA.

Wilcove, D. S., D. Rothstein, J. Dubow, A. Phillips, and E. Losos. 1998. Quantifying threats to endangered species in the United States. Bioscience 48:607-615.

Wood, A. 2000. An emerging concensus on biodiversity loss. Pages 1-10 in A. Wood, P. Stedman Edwards, and J. Mang, editors. The root causes of biodiversity loss. Earthscan Publications, London, UK.

Woodroffe, R., and J. R. Ginsberg. 1998. Edge effects and the extinction of populations inside protected areas. Science 280:2126-2128.

World Conservation Union. 1978. Categories, objectives and criteria for protected areas. World Conservation Union, Commission on National Parks and Protected Areas, Gland, Switzerland.

World Conservation Union. 1994. Guidelines for protected areas management. World Conservation Union, Gland, Switzerland. 